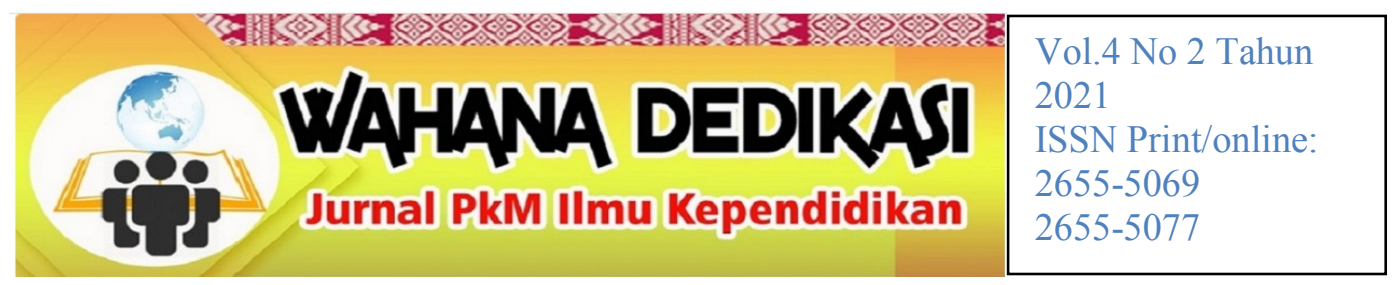

\title{
PELATIHAN PERENCANAAN DAN PENERAPAN MEDIA LOOSE PARTS DALAM PEMBELAJARAN ANAK USIA DINI BAGI GURU PAUD KECAMATAN RUMBAI PESISIR
}

\author{
Destina Kasriyati ${ }^{1}$, Sri Wahyuni ${ }^{2}$, Reswita ${ }^{3}$ \\ ${ }_{1,2,3}$ Universitas Lancang Kuning, Pekanbaru Riau \\ ${ }^{1}$ destina@unilak.ac.id, ${ }^{2}$ sriwahyuni91@unilak.ac.id'2,reswita@unilak.ac.id ${ }^{3}$
}

\begin{abstract}
Abstrak
Masa kritis bagi anak merupakan masa emas, dan perkembangan yang diperoleh pada tahap ini sangat mempengaruhi perkembangan periode berikutnya hingga dewasa. Mengingat pentingnya tumbuh kembang anak, maka perlu diberikan stimulasi yang tepat. Namun pada kenyataannya tingkat pemahaman para pendidik PAUD masih sangat rendah. Banyak pendidik telah terpengaruh oleh model pembelajaran tradisional dan monoton. Berdasarkan permasalahan tersebut, Pendidikan Anak Usia Dini (PAUD) perlu melakukan inovasi pembelajaran untuk membuat anak senang, salah satunya adalah penggunaan media yang longgar.Hasil dari pelatihan penerapan loose part bahwa $67 \%$ peserta atau sekitar 10 orang paham dalam mengikuti atau memahami metode loose part, sedangkan terdiri dari 20\% peserta atau sekitar 3 orang hanya memiliki tingkat pemahaman sedikit paham dan yang terakhir terdapat 13\% atau 2 peserta tidak paham dalam mengikuti pelatihan ini.
\end{abstract}

Kata Kunci: Media, Loose Parts, Anak Usia Dini

\begin{abstract}
The critical period for children is the golden period where the development obtained at this stage greatly influences the development of the next period until adulthood. The importance thing of early childhood development, it is necessary to provide the right stimulus. However, in fact in the field the understanding of early childhood educators towards children is still low. Many educators have been patterned with traditional and monotonous learning. Based on these problems, early childhood education (PAUD) requires learning innovations to make it fun for children, one of which is by using loose parts media. The results of the loose part implementation training showed that $67 \%$ of the participants or about 10 people understood the loose part method, while $20 \%$ of the participants or about 3 people only had a low level of understanding and the last $13 \%$ or 2 participants did not understand. in attending this training.
\end{abstract}

Keywords: Media, Loose Parts, Early childhood

Artikel disetujui tanggal:16-07-2021

Corresponden Author:Destina Kasriyati e-mail: destina@unilak.ac.id

DOI: http://dx.doi.org/10.31851/dedikasi.v4i2.5906 doi 


\section{W/AHANA DEDIKASI}

\section{PENDAHULUAN}

Pengertian pendidikan anak usia dini didasarkan pada ketentuan Pasal 1 Ayat 14 UU Sisdiknas tahun 2003: Pendidikan anak usia dini adalah suatu pembinaan bagi anak sejak lahir sampai dengan usia enam tahun, dan membantu pertumbuhan dan perkembangan jasmani dan rohani. dengan memberikan stimulasi pendidikan. , Mempersiapkan anak untuk melanjutkan pendidikan. Batasan lain usia anak usia dini berdasarkan psikologi perkembangan adalah antara 0-8 tahun. Selain istilah pendidikan anak usia dini, ada juga istilah pengembangan anak usia dini, yang mengacu pada upaya masyarakat atau pemerintah untuk membantu anak usia dini mengembangkan potensinya secara maksimal di bidang pendidikan, gizi dan kesehatan (Dewan PADU, 2002).

Berbagai hasil penelitian menunjukkan bahwa anak usia dini merupakan masa emas perkembangan anak, dimana $50 \%$ perkembangan intelektual terjadi antara usia 0-4 tahun, dan $30 \%$ berikutnya terjadi sebelum usia 8 tahun. Masa emas ini juga merupakan masa kritis bagi anak-anak, dan perkembangan yang diperoleh pada masa ini sangat mempengaruhi perkembangan masa selanjutnya hingga dewasa. Periode ini hanya satu kali dan tidak bisa ditunda, jadi jika dilewatkan berarti kesempatannya sudah habis (Permono 2013). perkembangan anak usia dini ini, maka perlu diberikan stimulus yang tepat. Namun kenyataannya di lapangan, seperti apa yang disampaikan (Widawati, 2010) Pendidik PAUD memiliki tingkat penguasaan anak yang sangat rendah. Banyak pendidik menggunakan pembelajaran tradisional sebagai model karena sering melihat pembelajaran pendidikan dasar lebih dulu dikembangkan di masyarakat. Pendidikan kelas dengan meja dan kursi belajar adalah salah satu mode pembelajaran yang umum digunakan dalam kelompok permainan. Padahal, proses belajar sebenarnya bisa berlangsung di mana saja, termasuk di luar ruangan atau di alam bebas.

Proses belajar ini menghalangi anak untuk mengerahkan kemampuannya secara penuh. Berdasarkan permasalahan tersebut, maka PAUD memerlukan inovasi pembelajaran agar menyenangkan bagi anak. Hal ini dapat membantu tumbuh kembang anak. Di Scotlandia pembelajaran yang menjadi viral adalah pembelajaran anak usia dini dengan menggunakan media loose parts. Dengan media ini, dapat meningkatkan keterampilan, struktur kognitif dan motorik anak didik karena anak didik memiliki kebebasan untuk menentukan dan menggunakan media tersebut sesuai apa yang dia fikirkan untuk menyelesaikan tantangan atau tugas yang diberikan. Hal ini menyebabkan anak didik terbiasa untuk berfikir secara komprehensif, kreatif dan kritis untuk menyajikan produk loose parts yang terbaik.

Loose part adalah bahan yang 


\section{W/AHANA DEDIKASI}

dapat dipindahkan, dibawa, sekeliling mereka, seperti bahan loose dihubungkan, didesain ulang, dipisahkan, dan dipasang kembali dengan berbagai cara. Loose Parts menciptakan kemungkinan kreatif yang tidak terbatas dalam kegiatan belajar dan merangsang kreativitas anak. Loose parts adalah media pengajaran yang tidak pernah berakhir yang digunakan dalam pembelajaran anak-anak. Media ini dari buku teks dapat digunakan sebagai alat untuk mengeksplorasi semua aspek: pemecahan masalah, kreativitas, konsentrasi, motorik halus, motorik kasar, sains (sains), pengembangan bahasa (literasi), seni (seni), berpikir logis dan matematika. (Matematika), Rekayasa (Engineering), teknologi (Technology). Tujuan pembelajaran bahan ajar Loose part adalah: anakanak menggunakan prinsip penggunaan bahan ajar Loose part, memberikan permainan penuh kreativitas mereka, dan bebas membuat bahan ajar membongkar sesuai dengan imajinasi mereka sendiri; anak akan belajar menghargai bahan atau benda di sekitarnya, seperti loose parts secara alami; anakanak juga akan dapat berpartisipasi dalam menjaga lingkungan, ketika mereka memahami bahwa bendabenda lama dapat didaur ulang dan digunakan sebagai bahan bermain dan dirangkai menjadi benda-benda yang berguna; mereka akan menumbuhkan sikap ekonomi anak-anak .

\section{BAHAN DAN METODE}

Bahan utama yang digunakan untuk pelatihan ini yaitu loose part, bahan-bahan atau benda-benda di

parts alami.

Metode yang digunakan dalam kegiatan ini meliputi rangkaian kegiatan, mulai dari kegiatan analisis situasi berupa observasi lapangan dan wawancara hingga saran dan laporan kegiatan pengabdian kepada masyarakat. Kemudian ada pemanfaatan media virtual untuk melaksanakan kegiatan, terutama penggunaan grup WhatsApp, karena kondisi tidak mendukung kegiatan pelatihan secara langsung akibat pandemi covid 19.

Prosedur yang dilakukan dalam kegiatan pengabdian kepada masyarakat sebagai berikut:

a) Sesi 1

Tim pengabdian membuat group WhatApp dengan invite nomor WA guru-guru paud sekecamatan Rumbai pesisir, kemudian setelah terbentuk group WA yang terdiri dari 15 guru-guru PAUD, maka kegiatan siap dilaksanakan

$\begin{array}{rlr}\text { Pada } & \text { sesi ini dilakukan } \\ \text { persiapan } & \text { materi } & \text { Pelatihan }\end{array}$
Perencanaan dan Penerapan Media Loose Parts dalam Pembelajaran Anak Usia Dini Bagi Guru PAUD Sekecamatan Rumbai Pesisir. Metode yang digunakan adalah metode ceramah dan diskusi untuk menjelaskan materi tetapi dengan cara diskusi melalui WhatApp group. Mekanisme dalam pelatihan ini meliputi:

1. Masing-masing peserta
membaca Materi seminar
yang sudah di kirimkan di
group WA sekitar 5-15 menit




\section{WAHANA DEDIKASI}

2. Selama kegiatan berlangsung peserta diharapkan menyimak dari awal sampai akhir kegiatan

3. Peserta tidak diperkenankan keluar group di saat kegiatan berlangsung hingga akhir kegiatan

b) Sesi 2

Pada sesi kedua pelaksana kegiatan membuka group WA dengan memperkenalkan anggota tim dan menyampaikan tujuan dari kegiatan ini kemudian menyampaikan materi yang terkait dengan topik yaitu loose part. Setelah materi dipaparkan melalui chat, peserta diberikan kesempatan untuk memberikan pertanyaan terkait dengan materi. Diskusi ini berlanngsung kurang lebih 2 jam.

\section{HASIL DAN PEMBAHASAN}

\section{Hasil}

Kegiatan dan pelatihan penerapan Loose part telah dilaksanakaan dengan menggunakan virtual media yaitu dengan media WhatsApp group yang diikuti oleh 15 peserta guru-guru PAUD sekecamatan Rumbai Pesisir. Kegiatan dan pelatihan ini berlangsung selama kurang lebih 3 jam dengan mekanisme perkenalan, diskusi dan tanya jawab yang dilakukan oleh tim pengabdi, tim ahli dan peserta pelatihan. Pelatihan penerapan loose part melalui WhatsApp group juga memiliki daya tarik bagi peserta untuk mengikuti pelatihan ini, hal ini terlihat dari beberapa peserta yang banyak memberikan tanggapan dan pertanyaan tentang loose part. Diakhir kegiatan pelatihan ini tim pengabdi juga memberikan atau menyebarkan angket melalui google form untuk melihat seberapa besar pemahaman peserta kegiatan dalam memahami loose part:

Diagram 1. Persentase Pemahaman peserta pelatihan

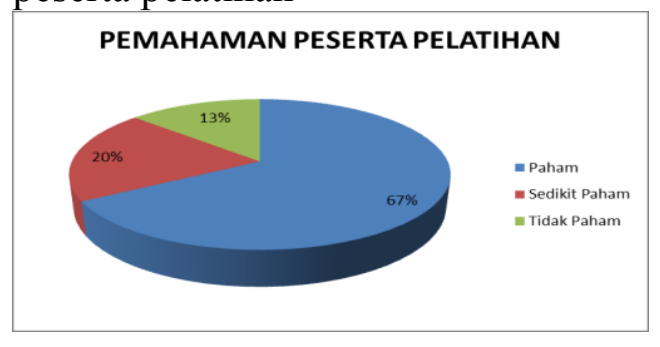

Berdasarkan diagram di atas bahwa kemampuan pemahaman peserta dalam mengikuti pelatihan loose part cukup baik. hal ini terlihat dari hasil angket yang disebarkan. Berikut ini hasil dari pelatihan terdapat $67 \%$ peserta atau sekitar 10 orang paham dalam mengikuti atau memahami metode loose part, sedangkan terdiri dari $20 \%$ peserta atau sekitar 3 orang hanya memiliki tingkat pemahaman sedikit paham dan yang terakhir terdapat $13 \%$ atau 2 peserta tidak paham dalam mengikuti pelatihan ini. Berikut ini yang disampaikan oleh peserta pelatihan setelah mengikuti pelatihan yaitu sebagian besar peserta mengatakan bahwa pelatihan ini sangat bermanfaat karena dapat menambah ilmu dan wawasan. Pelatihan ini juga dapat memberikan motivasi pendidik untuk lebih baik dalam pembelajaran dan merasa senang tentang pembelajaran dengan menggunakan media loose part. Peserta juga ada yang mengatakan bahwa loose part gampang dan mudah untuk dipahami. Selain itu, pelatihan 


\section{W/AHANA DEDIKASI}

loose part dapat meningkatkan ilmu tentang media yang digunakan ketika mengajar di sekolah PAUD.

\section{PEMBAHASAN}

Berbagai hasil penelitian menyebutkan bahwa masa usia dini merupakan periode emas bagi perkembangan anak dimana 50\% perkembangan kecerdasan terjadi pada usia 0-4 tahun, 30\% berikutnya hingga usia 8 tahun. Oleh sebab itu pendidikan yang diterapkan harus tepat dan cermat. Dimana tenaga pendidik harus menggunakan media pembelajaran yang efektif agar terciptanya peserta didik yang memiliki perkembangan kecerdasan yang diharapkan.

Berdasarkan hasil kegiatan yang dilakukan oleh tim pengabdian bahwa media loose part merupakan salah satu media yang efektif untuk meningkatkan perkembangan kecerdasan, selain itu media ini juga aman untuk digunakan karena menggunakan bahan-bahan yang alami. Oleh sebab itu media loose part dapat digunakan sebagai solusi para tenaga pendidik untuk meningkatkan perkembangan kecerdasan anak-anak. Seperti halnya yang dilakukan Kurniawan, K., Andriani, R., \& Kasriyati, D. (2017), dalam kegiatannya memberikan pelatihan media animasi untuk meningkatan kemampuan para guru dalam menggunakan media pembelajaran.

Hasil kajian dari Pratama, A., Fakhrudin, A., Kuswidyanarko, A., Riyanti, H., Nurhasana, P. D., Rizki, M., \& Setiawan, R. (2021) tentang workshop Pembelajaran kreatif sekolah dasar di seberang Ulu II telah memberikan workshop dengan tujuan meningkatkan kratifitas guru dalam proses pembelajaran daring untuk membuat pembelajaran yang kreatif. Sejalan dengan kegiatan yang dilakukan oleh Andriani, R., \& Kasriyati, D. (2018). Pembuatan Media Pembelajaran Berbasis Multimedia bagi Guru Sekolah Dasar (SD) Kecamatan Rumbai Kota Pekanbaru Provinsi Riau. JABDIPAMAS (Jurnal Pengabdian Kepada Masyarakat), 2(2), 119-126, bahwa kegiatan ini mampu memotivasi peserta untuk meningkatkan kemampuan dalam mengembangkan dan menggunakan multimedia sebagai media pembelajaran di kelas.

\section{KESIMPULAN}

Dalam kegiatan pelatihan penerapan loose parts yang dilaksanakan melalui whatsApp group, dengan diikuti oleh 15 peserta guru PAUD sekecamatan Rumbai pesisir dapat disimpulkan bahwa sebagian besar peserta paham dalam menerapkan loose parts dalam pembelajaran di sekolah pendidikan anak usia dini. Karena loose parts sangat mudah dan efektif diterapkan dalam pembelajaran. Selain itu media loose parts ini dapat memotivasi peserta didik dalam belajar sehingga dapat memudahkan guru dalam mengajar di sekolah. Kemudian media loose part juga terbuat dari benda benda yang bisa dibongkar pasang yang terbuat dari bahan alam dan bahan sintetis, sehingga aman digunakan.

\section{Ucapan Terimakasih}

Tim Pengabdi mengucapkan ribuan Terima kasih kepada Lembaga 


\section{WAHANA DEDIKASI}

Penelitian dan pengabdian kepada Masyarakat (LPPM) Universitas Lancang Kuning yang telah mendanai kegiatan pelatihan loose part. Selanjutnya ucapan terima kasih kepada para peserta atau Guru-guru PAUD sekecamatan Rumbai Pesisir yang telah bersedia sebagai mitra dan meluangkan waktunya untuk kegiatan pelatihan ini. Tanpa Peserta dan lembaga LPPM kegiatan ini tidak dapat berjalan dengan lancar.

\section{DAFTAR PUSTAKA}

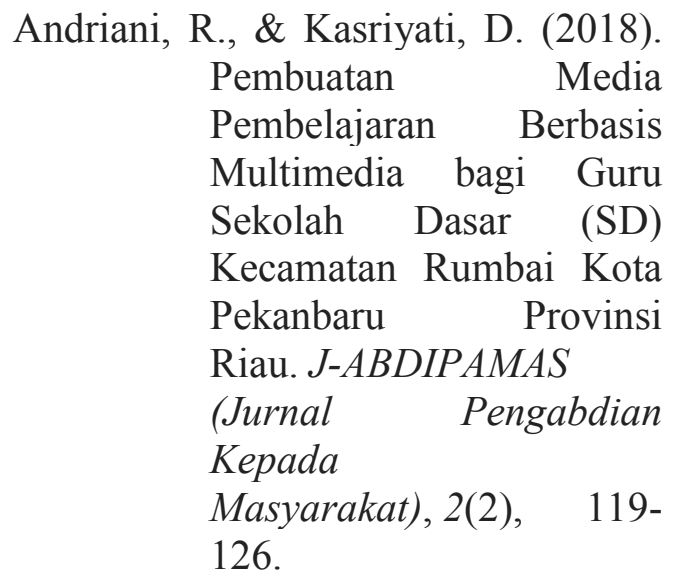

Anna Permanasari. (2016). STEM Education: Inovasi dalam Pembelajaran Sains. Jurnal Kimia UPI. Bandung: Universitas Pendidikan Indonesia

Direktorat PADU (2002). Acuan menu pembelajaran pada pendidikan anak dini usia (Menu Pembelajaran Generik) Jakarta : Direktorat PADU - Ditjen PLSPDepdiknas.
Kurniawan, K., Andriani, R., \& Kasriyati, D. (2017). Pengembangan Media Animasi Untuk Pembelajaran Bahasa Inggris Sekecamatan Rumbai Kota Pekanbaru. Dinamisia: Jurnal Pengabdian Kepada Masyarakat, 1(1), 68-73.

Permono, H. (2013). Peran Orangtua Dalam Optimalisasi Tumbuh Kembang Anak untuk Membangun Karakter Anak Usia Dini. Universitas Persada Indonesia, Jakarta. Diakses 07 Februari 2020, dari https://publikasiilmiah.ums.ac.i d/bitstream/handle/11617/3994 102.pdf?seq

Pratama, A., Fakhrudin, A., Kuswidyanarko, A., Riyanti, H., Nurhasana, P. D., Rizki, M., \& Setiawan, R. (2021). Workshop Pembelajaran Kreatif Sekolah Dasar Di Seberang Ulu II. Wahana Dedikasi: Jurnal PkM Ilmu Kependidikan, 4(2).

Widawati. (2010). Implementasi Pembelajaran Berhitung di Taman Kanak-kanak Melalui Pendekatan Matematika Realistik. Skripsi Sarjana pada FIP UPI. Bandung. Tidak diterbitkan 